Edgar, B. D. \& Willinsky, J. (in press). A survey of the scholarly journals using Open Journal Systems. Scholarly and Research Communication.

\title{
A Survey of the Scholarly Journals Using Open Journal Systems
}

\author{
Brian D. Edgar and John Willinsky
}

\begin{abstract}
A survey of 998 scholarly journals that use Open Journal Systems (OJS), an open source journal software platform, captures the characteristics of an emerging class of scholarpublisher open access journals (with some representation from more traditional scholarly society and print-based titles). The journals in the sample follow traditional norms for peerreviewing, acceptance rates, and disciplinary focus, but are distinguished by the number that offer open access to their content, the growth rates in new titles, the participation rates from developing countries, and the extremely low operating budgets. The survey also documents the limited degree to which open source software can alter a field of communication, as OJS appears to have created a third path, dedicated to maximizing access to research and scholarship, as an alternative to traditional scholarly society and commercial publishing routes.
\end{abstract}

Keywords: Online publishing, journal survey, open source software, open access

\section{Introduction}

Open Journal Systems (OJS) is an online journal management and publishing platform that was first launched in 2002 as open source software freely distributed by the Public Knowledge Project (Willinsky, 2005). ${ }^{1}$ The software had been developed as part of the Public Knowledge Project's research program at the University of British Columbia in Vancouver, Canada, under the direction of John Willinsky, with subsequent participation by Simon Fraser University Library, the Canadian Centre for Studies in Publishing, and Stanford University. OJS was originally programmed by undergraduate computer science students at UBC, led by Kevin Jamieson, with a research grant from the Social Sciences and Humanities Research Council of Canada that sought to explore the feasibility and consequences of helping print journals to publish their content online.

OJS was designed to manage the journal's workflow, from manuscript submission through review to editorial work and then publication, while offering a ready means of publishing an online edition, while better manage the journal's operating costs (Willinsky, 2006). This system was developed within a climate of concern among journal editors and staff over the costs and means of

\footnotetext{
${ }^{1}$ On the economic role and place of the open source software more generally, Vance provides an apt summary: “There's an open-source alternative, and usually a pretty good one to just about major commercial software product. In the last decade, there open-source wares have put a tremendous pricing pressure on their proprietary rivals. Government and corporations have welcomed this competition" (2009, p. B6). Also, on the scholar publisher, see the Open Access Scholarly Publisher's Association, which has a special membership category for OA scientist/scholar publisher (http://www.oaspa.org/).
} 
moving from print to online editions, as well as over the viability of open access models (by which, for example, authors make articles freely available through online institutional repositories and journals make their content freely accessible to readers). These concerns continue to affect social science and humanities journals published by small societies and groups of scholars (Lorimer, Lynch, \& Provençal, 2006).

This study reports on the OJS experiment, involving the introduction of open source software systems into a site of considerable transformation, namely scholarly communication in the twenty-first century. OJS is but one of a number of open source journal management systems (see Cyzyk \& Choudhury, 2008, for a review of comparable systems). It is being used by approximately 5,000 journals, has had 19 upgrade releases since its was first made available in 2002, and is now available in 20 languages. It is currently supported by a team of programmers led by Alec Smecher and managed by Brian Owen, in association with Simon Fraser University Library, with funding from a variety of granting agencies and, to a lesser degree, service and hosting contracts.

In March 2009, we conducted our first survey of journals that deploy OJS, and this paper reports on the results of that survey to which 998 editors or staff members responded. The results point to how these journals - largely independent, scholar-published titles with roughly half originating in the developing world - are not otherwise represented in current and pressing discussions on the future of scholarly publishing, especially when it comes to matters of journal costs, revenues, and publishing models. This paper begins with a brief review of a selected set of previous surveys of scholarly journals, looking specifically at questions that bear on this current study, including the steady growth of journals, the distribution of different publisher types, and (the variance in) costs involved in journal publishing.

\section{Previous Journal Surveys}

David A. Kronick has surveyed seventeenth and eighteenth century journals, providing a strong sense of historical continuities and breaks that include concerns over the fragmentation of knowledge (1961, p. 75); the tendency of journals to go out of business within five years (1961, p. 91); and the need for multiple reviewers (Kronick 2004, p. 124). Kronick also documents the early preponderance of independent journals (neither society nor commercially published) - with particular pertinence to this survey - with that dominance persisting until the middle of the nineteenth century, after which society-sponsored journals prevailed, followed by, in the latter half of the twentieth century, the growing market share of corporate journal publishers (2004, p. 123).

In terms of contemporary journal publishing, the U.S. National Science Foundation's Office of Science Information Service (OSIS) conducted and sponsored a number of surveys. In 1954, Robert Tumbleson and Helen L. Brownson published an OSIS study of 100 journals, establishing 
that editorial costs ranged from 2 to 11 percent of the journal's total expenses, while printing-related costs ranged from 65 to 80 percent, with the higher figure holding for the relatively common smallercirculation journals, with less than a 1,000 subscribers (1954, p. 358). Authors faced publication charges with 16 of the journals, while an additional 11 charged for publishing "longer" articles (p. 359).

In a 1959 OSIS study found that 80 percent of the 262 scholarly journals surveyed were published by scholarly societies, with 13 percent published by commercial presses, and 7 percent by university publishers (OSIS, 1964, p. 2). The university and society journals were older and more established, with average ages of 41 and 33 years, respectively, compared to the average age of the commercial journals, which was 17 years (p. 2). During the previous 10-year period, from 1949 to 1959, 74 new journals were launched, with 26 percent published by commercial ventures, suggesting that the commercial publishers were beginning to take a more active role in launching new journals compared to the scholarly societies, in a trend that would continue through to the end of the century and beyond (Willinsky, 2009, p. vii).

The OSIS study established that subscriptions to the commercial publishers' journals cost twice as much as those for scholarly society and university journals (p. 9). The OSIS study also estimated the average operating costs per journal to be $\$ 31,500$ (in 2008 dollars), of which 68 percent could be attributed to printing costs. Editors were reported to be working 711 hours annually on their journals, with 40 percent of them receiving some form of remuneration for these efforts, with editors of commercially published journals tending to work fewer hours (478 hours on average) while being somewhat more likely (52 percent) to be paid (p. 16). Journals were also growing larger during this period, with a 52 percent increase in the number of articles published per journal from 1949 to 1959, moving from 83 articles to 126 articles per year (p. 6). However, society and commercial journals were also making efforts to reduce the length of individual articles and print more words per page as a means of decreasing production costs. University presses, on the other hand, continued to print longer articles with fewer words per page than society and commercial presses. The authors of the OSIS note ominously that "if they are to continue to publish journals, [university presses] will probably, very soon, have to face the stern realities of economics that the society journals are in the midst of combating" (p. 16).

In 1976, Bernard M. Fry and Herbert S. White found that, in a survey of 254 U.S. journals, 114 of the titles were published by scholarly societies, with 50 titles held by commercial publishers and 34 titles handled by university presses, leaving 56 titles in the category of other (1976). Fry and White found that between 1969 and 1973, the number of journals grew by 3.9 percent overall, although this growth rate was now more than double for commercial publishers (p. 71). As well, commercially published journals were nearly double in size of those from other publishers (with 
1,010 pages annually), justifying their additional costs and demonstrating their willingness and ability to respond to the increased research output experienced during this period. ${ }^{2}$ Fry and White also found the situation for scholarly society journals, as well as for university press journals, "depressed and depressing," with university presses consistently losing money, while societies managed to recoup roughly a 3 percent surplus from subscription sales over their costs (p. 81). Commercial publishers, on the other hand had returns in the area of 11-14 percent, partially through their ability to attract a greater proportion of international subscribers (p. 76). Fry and White hoped that better information about the costs of publishing might lead to "proposed joint actions by publishers and research libraries aimed at achieving cooperative and reasonable results to both communities" (p. 1). The situation also called for, in their eyes, federal subsidies for libraries, publishers, and authors (pp. 122-123).

Following close on the heels of Fry and White, Fritz Machlup and Kenneth Leeson published a study of 171 journals, evenly divided between society and commercial publishers (1978). Machlup and Leeson also found that university presses lost money, while society and commercial publishers were increasing prices, generating surpluses of $\$ 193,030$ (in 1975 dollars) in the case of societies and $\$ 133,800$ among commercial presses (p. 176). However, the size of the price increases favored the commercial publishers, which were in this period charging twice the price of society journals on average (and six times that of university press journals), although commercial publishers did offer larger journals. The publishing costs for the journals varied from $\$ 10,200$ to $\$ 1,195,800$ annually, with a mean of $\$ 214,000$ (p. 156). ${ }^{3}$

At the beginning of the twenty-first century, Carol Tenopir and Donald W. King reported that among 6,771 titles published in the U.S. in 1995, 40 percent were commercially published, 23 percent by scholarly societies, 16 percent by educational publishers including university presses, and 21 percent by "others" (2000, p. 237). Tenopir and King estimate that publication expenditures were $\$ 4,550$ per article or $\$ 325$ per page in 1995 (p. 264), with $\$ 20$ per manuscript page spent for "manuscript receipt processing, the selection of at least two reviewers, and review processing" (p.

\footnotetext{
${ }^{2}$ On the research expansion following the Second World War, see Tumbleson and Brownson: "Estimates of the Research and Development Board, Department of Defense, indicate that total expenditures for research and development have increased from $\$ 900$ million in 1942 to $\$ 2,900$ million in 1952 . The industrial contribution has gone from $\$ 500$ million to $\$ 1,200$ million in this ten-year period while that of the federal government increased from $\$ 300$ million to $\$ 1,600$ million. The university contribution has doubled-from $\$ 50$ million to $\$ 100$ million in the same period" $(1954$, p. 357). This was the period when the commercial journals stepped in, providing a much needed outlets for the resulting work (Willinsky, 2009).

${ }^{3}$ As Donald W. King, Denis D. Macdonald and Nancy K. Roderer note in their study at this time, "journal resource expenditures" grew 584\% between 1960 and 1975, well in excess of the corresponding growth (153\%) in research funds during that period (1981 p. 37). In calculating expenditures, King, Macdonald and Roderer introduce the concept of "donated services," referring to the contributions of author, subject editor, and reviewer, placing the total value of this donation at $\$ 174,300$ in 1977 , compared to actual publications costs of $\$ 120,400$ for the average journal in that year (p. 118).
} 
257). They also estimate that for a new journal, it would take an investment of $\$ 63,187$ in advance of printing first issue (p. 307), while for an electronic journal they report that American Psychological Association estimated start-up costs of $\$ 181,000$ for basic system costs and licensing fees (p. 373).

In 2007, after reviewing "hundreds of publications on the topics of the cost and price of journal publishing," Donald W. King noted how this literature was marked by inconsistencies in measurement and ambiguities in the very terms and concepts used (2007, p. 85). Still, King was able to summarize a dozen studies on the question of first-copy publishing costs (excluding distribution costs) in 2006 dollars, showing a range from $\$ 450-2,500$ per article, for one study of 10 publishers, to $\$ 2,540-11,420$ per article for a MIT Press study (p. 95). To those “fixed, direct costs," King points out that expenses needed to be added for "conducting business," which includes "headquarters, general and administrative (G\&A), and overhead" increasing the per-article expense by 20 and 50 percent (p. 99). ${ }^{4}$ King provides an explanation for the wide variation in costs among publishers that includes such factors as rejection rates and "the characteristics of resources employed" (p. 104).

Also since the turn of the century, a number of surveys have focused on the impact that open access to research is having on the citation and "hit" rate of the scholarly literature (Hitchcock, 2009). These surveys have established that when open access is provided to an article, whether through authors self-archiving their own article or having it published in an open access journal (Harnad et al., 2008), open access has been shown to lead to an increase in readership (e.g., Davis et al., 2008) and an increase in citations (e.g., Eysenbach, 2006) when compared to similar work that has not been made open access.

Finally, Mark Ware and Michael Mabe have recently released The STM Report: An Overview of Scientific and Scholarly Journals Publishing (2009), which sets out the scale of an $\$ 8$ billion industry (for STM journals), representing 25,000 titles (across all fields) with that number growing at a rate of 3.5 percent a year over the last two centuries (p. 18). Ware and Mabe point to how commercial publishers now constitute 64 percent of the journals listed in the highly selective ISI Web of Science index (p. 24). ${ }^{5}$ They hold that the number of active authors drives the scale of publishing, with only 20 percent of the estimated 5.5-10 million researchers worldwide active in the sense of having published more than once (p. 19). That the increase in the number of journal titles (and number of articles) currently matches growth of "US R\&D workers" only adds to the sense of constrained global participation in scholarly publishing (p. 23). Ware and Mabe report that 90 percent of journals in all

\footnotetext{
${ }^{4}$ King cites a study by Page Campbell and Meadow (1997) that places the "marketing and sales" costs of starting a journal at $\$ 36,000-56,000$ over five years in order to achieve 500 subscribers (2007, p. 98), a figure which is otherwise placed in the areas of 6-15\% of costs for existing journals by other studies (p. 99).

5 The figure for commercial titles compares well to Raym Crow's estimates from 2005 for all journals listed in Ulrich's Periodical Director, a much more comprehensive source, which places commercial publishers at 63\% (with about a quarter of those published on behalf of societies) of the market, while scholarly societies still publish $23 \%$ of the journals on their own, leaving 15\% as "other," such as universities (2005).
} 
academic areas are now online, with only 2 percent of these titles publishing in an open access format (pp. 19, 20). They estimate that the cost of seeing through an article to publication, "excluding noncash peer review costs," at $\$ 3,800$ (p. 52). ${ }^{6}$ They note both that this figure is higher than the typical "article processing fees" that are now charged by open access biomedical journals, while also observing that such fees cannot be applied to all fields, given that 25 percent of researchers work in developing countries and 60 percent do not have "separately identifiable research funding" that might cover those costs (p. 52). ${ }^{7}$

This brief survey of research on scholarly journal publishing points to the challenges of formulating an accurate, systematic picture. Judging by the estimates provided, very different economic models have developed over time among profit and non-profit publishing interests for providing essentially the same services in publishing the research article. It is not clear the degree to which the large differences in costs and pricing is necessary nor how well it serves the larger scholarly communication goals of advancing research and scholarship. The study presented here further complicates the picture by presenting data that only adds to the difference in costs presented in the previous studies, but it also demonstrates a revitalization of the independent journal which has not been well represented in previous studies. This loosely grouped class of journals, sharing a common open source software system, casts new light on, among other things, journal cost structures (fixed, direct and indirect); the growing dominance of the commercial publishers; the sense of a steady, modest growth rate in journal titles; and the participation, more generally, of researchers in the production of research and scholarship on a globally accessible scale.

\section{Methodology}

The sample for this study was assembled by conducting a search on distinct terms used by the Open Journal Systems software, leading to the identification of a pool of 3,000 titles in January 2009, after eliminating those that were clearly demonstration or test installations. Some of the journals we retained in our sample had not yet published an issue (and some had been established prior to 1900). From the journal sites that we have ascertained, we were able to locate a contact name and email address for what proved to be 2,748 editors or journal managers (as some journals had out-of-date email addresses) to which we sent an invitation to participate in an online survey that was hosted by Survey Monkey.

\footnotetext{
${ }^{6}$ This might be compared to a more recent CEPA study that placed the "total publishing and distribution costs per article” at $\$ 6600$, while being clear that this differed by disciplines (CEPA, 2008, p. 6).

7 On "article processing fees," see the 2004 Wellcome Trust report, prepared by SQW Inc., with such fees presented as a potential path to open access for a greater circulation of research and a reduced cost per article, as there is no need to "carry any costs for subscription management, license negotiations, or many sales costs" (SQW, 2004, p. 2).
} 
The survey included sections on journal basics, editorial process, economic model, readership and indexes, contributions and challenges. Of the 2,748 invitations that we believe were received, 998 provided usable responses to the survey for a response rate of 36 percent. The survey was in English, and given the variety of languages into which OJS has been translated, this undoubtedly affected the distribution of responses, although each of the world's regions are represented in the surveys submitted, with South America the strongest area of response, led in large measure by Brazil (Figure 1). ${ }^{8}$ The Public Knowledge Project has focused a good deal of its support, through workshops and other initiatives (with funding from IDRC, INASP, McArthur Foundation, and Mellon Foundation) on journals located in the "developing world," and these amounted to 47.9 percent of the sample that completed the survey.

Figure 1 about here

\section{Survey Results}

\section{Journal Basics}

Among the close to a 1,000 titles in this sample, 40 percent published research in the sciences, technology and medicine, 30 percent were social science journals, and 11 percent were in the humanities (Table 1). This distribution reflects the general pattern of take-up in online publishing, which has been led by the sciences, with the humanities still catching up. However, 19 percent of the journals in the study cut in interdisciplinary ways across these three broad areas, by publishing, for example, in global or regional studies, or by representing the work of a university or other institution. This list of journals also includes highly specialized titles - on virtual worlds, surveillance studies, architecture and environment, Foucault studies, violence injuries, clinical governance - which suggest how scholar publishers can more readily support the emergence of new areas of study and new approaches to scholarship, which has its risks, certainly, in terms of the proliferation and disappearance of titles, but which also can be seen to open doors in the pursuit of academic freedom (Willinsky, Murray, Kendall, \& Palepu, 2007).

Table 1 about here

${ }^{8}$ A follow-up survey in Portuguese based on the similar questions is underway in Brazil. 
In marked contrast to the findings of other studies, only 6 percent of these journals are published by commercial houses, compared to the 64 percent reported by Ware and Mabe (2009) and Crow (2005). Scholarly societies published 32 percent of the titles in this sample, exceeding the 23 percent that Crow found scholarly societies "self-publishing" in his study of journals as a whole (with societies having turned over 17 percent of the journals being published to commercial publishers to publish on the society's behalf). This leaves the vast majority of the journals in this sample as published or sponsored by an academic department (51 percent), a non-profit publisher (16 percent), research unit (10 percent) and independent group (10 percent), although these percentages cannot be added up, as respondents could choose more than one sponsor (Table 2). As well, it needs to be allowed that commercially published journals would be less likely to complete such a survey, given a noted reluctance among this constituency to share information about publishing practices (Houghton et al., 2009). Still, these results suggest that the majority of these journals fall into what can be identified as the independent or scholar-publisher titles.

Table 2 about here

The majority of the journals using OJS are twenty-first-century products of the digital era (Figure 2). The number of journals that are employing OJS has been growing at a rate of 81 percent per year on average since the software was launched in 2002. The number of new journals using this software to start publishing has been increasing at a rate 47 percent, beginning in 2005 when the software began to catch on. This level of growth can be compared to Ware and Mabe's finding that "the number of peer reviewed journals published annually has been growing at a very steady rate of about 3.5 percent per year for over three centuries (2009, p. 18). While OJS is helping a new wave of journals take hold, at least five of the titles now using OJS were launched prior to 1900, and 216 titles were started prior to the appearance of the World Wide Web in the early 1990s. As well, a small number of journals (7 percent) have taken advantage of OJS's capacity to import back issues to enable online readers to access issues that were published prior to the internet (Table 3). Close to half of the journals ( 45 percent) report having had print editions at some point in their publishing histories, even as the majority of these journals printed less than a 100 copies (with three journals printing over 5,000 copies). This suggests that roughly half the journals using this software are "born digital," with a majority of them using OJS from the outset.

Figure 2 about here 
Table 3 about here

\section{Editorial Practices}

One measure of the size and vitality of the journals comes from the number of manuscript submissions they receive. In this case, submissions ranged from zero in the previous month for the 8 percent of journals that have yet to get underway (although they may be open and have yet to receive any submissions), to the small number (3 percent) that are taking in more than 60 submissions a month (Table 4). The majority of the journals (52 percent) are receiving between 1 and 10 submissions a month. This reflects the "youth" of these journals as well as the fact that close to half of them are published in developing countries, where working conditions often do not support a very productive research culture (as faculty members have to hold multiple jobs to sustain a living). As for these journals' rate of publication, they produce 31 articles a year on average. This falls considerably short of Björk, Roos and Lauri estimate for ISI Web of Science journals, which they place at 111 articles annually (with such productivity a quality measure for ISI), yet it does compare to the average of 26 articles they found among journals not listed in ISI (2009).

Table 4 about here

Articles that are submitted to a scholarly journal typically go through a peer review process. Within this sample of journals, 89 percent of the journals use external peer reviewers, with over half of the journals drawing reviewers from an international pool of scholars and assigning more than one reviewer to a paper (Table 5). The review process is blind in the majority of cases, with authors' names kept from reviewers among 70 percent of the journals, and reviewers' names kept from authors among 82 percent of the journals.

Table 5 about here

A journal's acceptance rate for submissions, following this review process, is typically regarded as one measure of journal quality (Table 6). Of the journals actively publishing issues in this sample, the acceptance rate was relatively evenly distributed, with 115 journals having a very lenient acceptance rate of over 90 percent, and with 155 journals with a very stringent acceptance rate of 
below 30 percent. Houghton et al. report a "consensus from the literature" that places the rejection rate at 40-60 percent, which a majority of the journals in this sample adhere to or exceed in rigor (2009, p. 154).

Table 6 about here

\section{Journal Staffing}

The journals in this sample are staffed, on average, by seven editors, with 30 percent of the journals operating with more than six editors (Table 7). The commercial publisher Elsevier, which publishes 2,000 journals, averages 3.5 editors per journal (Elsevier, 2009). The greater number of editors, found in this study, enables the workload to be distributed, a process which is facilitated by having all of the relevant materials on the journal website. ${ }^{9}$ All of the journals reported that at least one of their editors was doing this job for the first time, and that at least one of the editors was from another country, speaking to the beneficial mentoring and international collaboration that the journals are fostering. The editors also indicated that they put roughly one day a week into editing the journals, with a few reporting on working full-time on the journals.

Table 7 about here

In terms of the distribution of publishing tasks, this group of journals represents very active editorial teams, with 76 percent of the editors engaged in copyediting, 70 percent involved in proofreading, and 58 percent taking a hand in laying out the articles (Table 8). This does not mean that the editors had sole responsibility for these tasks, although this does appear to be the case in at least some instances, while there are also journals with paid employees doing copyediting, layout, and proofreading. Students, whether paid or volunteers, play a relatively minor role in the production of these journals, with no more than 10 percent of the journals deploying students in this way. It is also worth noting that, although OJS is designed to enable the author to participate in both the copyediting (to review copyedits and respond to author queries) and proofreading, in the majority of cases the journals are not involving the authors in these tasks.

\footnotetext{
${ }^{9}$ In the eighteenth century, Denis Diderot emphasized the need for editorial collectives by claiming that "it was impossible for a single editor to issue even a mediocre journal" in writing about journals in the Encyclopédie, as "a journal must be the work of a society of scholars" (cited by Kronick, 2004, p. 106).
} 
Table 8 about here

Most editors (77 percent) reported working without compensation from the journal, with only 16 percent reporting some form of remuneration (Table 9). Understandably, most editors reported, in another item, that they were motivated to edit the journal by non-monetary concerns, with "service to community" and "providing new knowledge" topping the list. Among paid employees of the journal, the leading role was graphic designer, also known as layout editor (who turns the manuscript into the form of a publishable article). This was closely followed by technical support among paid roles, with 37 percent of the journals paying a fee for these services. On the other hand, 36 percent of the journals have unpaid and 25 percent have paid clerical support, which suggests that OJS is having only very limited success in reducing or replacing this aspect of scholarly publishing, which had been part of the thinking that had gone into its design (Willinsky, 2005). A small percentage of the peer reviewers used by the journals are paid ( 7 percent), and among the disciplines this appears to take place, if at all, in the field of economics.

Table 9 about here

\section{Journal Revenue, Expenses and Access Policies}

The journals completing this survey are tapping into all of the traditional sources that have been relied upon to fund scholarly publishing (Table 10). However, while a few journals are bringing in substantial amounts in certain categories, the vast majority are receiving no or relatively small amounts of revenue from these typical channels. The strongest source of revenue comes in the form of subsidies, which a third of the journals reported receiving, at an average $\$ 15,000$ per year. These subsidies, as well as grants, may be from the institution, the state, or a donor, and a number of programs exist for the subsidization of scholarly publishing (e.g., Lorimer, Lynch, \& Provençale 2006). Then there is, as well, the admittedly mysterious "other sources," for which 9 percent of the journals stated as a source of revenue for an average of $\$ 26,475$. Submission fees (used by 3 percent of the journals) and publication fees (9 percent), which are often held up as the open access model (although such fees for open access journals are principally applied in the case of biomedical journals), play a very small part in this class of journals.

Table 10 about here 
Subscriptions, principally from the print edition, where a source of revenue, on average $\$ 7,815$, for 25 percent of the titles in this sample, with 47 journals reporting subscription revenues of less than a $\$ 100$ a year (but greater than zero), while 10 titles collected over $\$ 10,000$ annually. Subscription-related expenses (print, postage, and subscription management) were higher than subscription revenues, on average, leaving a deficit of $\$ 4,174$ on average. Only 17 titles out of 247 produced a surplus of more than $\$ 100$ from its subscriptions, while 230 journals showed a loss of greater than $\$ 100$ a year, suggesting a need for at least a 50\% increase in subscription prices (which typically leads to a subscription cancellations). Alternatively, the journals might consider dropping print and subscriptions entirely. Yet at the same time, nearly 60 percent of the subscription journals experienced an increase in subscribers over the previous year (Table 11). These journals gained an estimated 124 subscribers on average (representing a 20 percent increase in average number of subscribers), although such increases could simply add to the deficit created by subscription-related expenses. The journals that offered free online access did gain somewhat more subscribers (and lost fewer) than titles for which both online and print editions required subscriptions.

Table 11 about here

This brings us to the journals' online access policies, which obviously also affect their revenue (Table 12). Most of the journals in this sample (83 percent) offer immediate open access to their online content. Among these open access journals, 20 percent continue to offer a print edition by subscription. A further 8 percent of the total number of journals provide a form of embargoed access, with their content being made freely available some months after publication. OJS does include a subscription module within the software that can restrict access to subscribers and subscribing institutions, with 11 percent of the journals requiring subscriptions for both online and print access. In addition, 13 percent of the journals permit authors to self-archive a copy of their article (typically the final peer-reviewed draft) in an institutional repository or on the author's website (with 1 percent allowing this only after an embargo period). ${ }^{10} \mathrm{~A}$ further analysis of the data reveals that only ten of the 87 journals that require subscriptions for both print and online permitted authors to immediately self-archive their work, while a further six permitted a form of embargoed access (pointing to a means of open access that OJS could do more in the future to support and encourage).

${ }^{10}$ While this may not seem necessary for open access journals, it is still a recommended practice in supporting these repositories and for posting preprints prior to publication. 
Table 12 about here

While there is strong support for open access within this sample of journals, it was not the factor that editors ranked highest, when asked what mattered most to authors in selecting a journal. Peer review did, with 85 percent ranking it very important or most important. Other important factors were journals appearing online (76 percent very important plus most important), being indexed (63 percent), and citation rates (61 percent); with possessing an open access policy (at 59 percent); and the related extent of the readership (57 percent). When Garvey asked a similar question of researchers, he found that a journal's ability to provide an appropriate audience was "the major basis" for opting to submit to that journal for fourth-fifths of the authors polled (1979, p. 212). Indexing, citation counts, and online access may well have complicated the sense of securing the appropriate audience, which used to be far more a matter of researchers reading selected journals rather than researchers searching relevant articles (Tenopir, King, Edwards, \& Wu, 2009).

One parallel that is sometimes drawn between open access journals and subscription journals is between "registered readers" and subscribers (Table 13). The registered reader is sent the table of contents with each new issue and it at least represents a level of interest in the journal, but then subscriptions do not guarantee readership either, even as they may well represent a library, which is increasingly likely as individual journal subscribers continue to decline (Tenopir \& King, 1998). The survey provided instructions on how to check for the number of registered readers using OJS, and while only 563 journals responded to this item, the average number of readers for those journals that had registered readers (and this option can be turned off in OJS) was 1,155, with the majority of journals coming in under 500. The 278 subscription journals had 611 subscribers, falling well within the broad range of 300 to 3,000 subscribers a recent report stated as typical of scholarly publishing (CEPA, 2008). ${ }^{11}$

Table 13 about here

In terms of publishing costs for the journals, a similar pattern to revenue unfolds, with some journals accruing expenses for all of the typical items, while not one item was an expense for the majority of journals. Journal printing (averaging $\$ 9,463$ annually) was the most common expense, with 40 percent of the journals noting charges for this item (Table 14). Postage (average \$2,526) was

${ }^{11}$ Kronick notes that in seventeenth-century journals were known to manage with less than 100 subscribers, while some had over 1,000; the first English-language journal Philosophical Transactions began with an ambitious printing of 1,000 copies (2004, pp. 194, 197). 
not far behind with 37 percent of the titles recording this as a cost. While the single most expensive item proved to be subscription management costs with an average of $\$ 12,728$ annually, only 4 percent of journals reported this expense. Still, given the average income from subscriptions of $\$ 7,815$ and the continuing questions about the sustainability of print editions, it would seem that journals in this sample may well welcome the initiative among libraries and readers generally to drop print journals and rely entirely on electronic editions (Prabha, 2007). As noted in journal staffing above, the management of the journal is a cash expenditure for at least 37 percent of these journals (somewhat higher than reported in Table 9) at an average cost of $\$ 9,053$ annually, while 24 percent pay for copyediting services (average $\$ 3,973$ ), 28 percent for layout $(\$ 2,756$ ), and 19 percent for proofreading $(\$ 1,613)$.

Table 14 about here

A further analysis of expenses was conducted to ascertain the "first copy" cost in preparing an article for publication. This is something of a standard economic measure in the publishing industry, and was calculated for this sample of journals by summing the means for editorial, management, copyediting, layout and proofreading expenses, including those journals that reported zero for these items (which is not otherwise the case for the means in Table 14 as noted). Using the average production of 31 articles annually for this set of journals, the average first copy cost of an article was $\$ 188.39$. This can be compared to first copy costs of $\$ 1,784$ per article calculated by Research Information Network based on a review of the research literature and their own survey (RIN, 2008, p. 35). ${ }^{12}$

In calculating the total revenues and expenses for individual journals, it appeared that 44 percent of the journals in the survey reported having zero revenue across all categories of revenue types, that is, they responded with a " 0 " rather than leaving it blank (Table 15). ${ }^{13}$ In addition, 16 percent were operating at $\$ 1,000$ or less in revenue annually. Among those that declared at least one source of revenue, the average annual income was $\$ 28,474$. A similar analysis of expenses revealed that a lower proportion (29 percent) was operating with zero expenses than was operating with zero revenue. An additional 20 percent declared expenses that did not exceed $\$ 1,000$ annually. For journals with expenses, the average annual cost was $\$ 16,951$.

\footnotetext{
12 The RIN notes the accord between its figures and King and Tenopir's calculations (1998), which used "typical" publishing costs to arrive at a first copy cost of $\$ 1,950$ (while allowing that figures "vary dramatically" among journals and publishers).

${ }^{13}$ For a detailed description of how a new journal operates (using OJS) on a zero-budget through the efforts of colleagues, see Willinsky and Mendis (2007).
} 
While it may be tempting to compare average revenues and expenses in this table - which reveal an annual surplus of 40 percent (compared to industry leader Elsevier's annual “operating profit margin" of close to 23 percent in the years 1998-2000; McGuigan \& Russell, 2008) - it may make more sense to calculate the revenue-expense balance by individual journal (Table 16). This determined that half of the journals were breaking even, while 18 percent ran a deficit of more than a $\$ 1,000$ annually, and 13 percent reported a surplus in excess of $\$ 1,000$. A comparison of subscription-related costs (printing, mailing, and subscription management) and subscription revenues suggests that this model leads to an average deficit of roughly $\$ 4,000$, while a journal-byjournal analysis points to 17 journals clearing more than a $\$ 100$ on subscriptions against such costs, while 374 journals roughly broke even, and 230 lost more than $\$ 100$.

Table 15 about here

Table 16 about here

A final analysis compared journals with either low acceptance rates (30 percent or lower) or high acceptance rates (70 percent or greater) across differences in budget, age, access principle, publisher type, and continent status (Table 17). This analysis revealed that fewer low-acceptance journals (generally a measure of higher quality journal content) are found in the "developing" continents of Africa and Latin America, compared to the developed continents. A greater proportion of subscription journals appear to have low acceptance rates than is the case among open access titles. Yet this matter of low acceptance rates does not appear to be a factor in distinguishing between society-sponsored journals and independent groups, nor between modestly and minimally budgeted journals, nor between older and new journals. On the other hand, high acceptance rates tend to be associated with a greater proportion low-to-no-budget journals, that are newer in origin, and that are scholar published rather than society sponsored. These comparisons speak to what it takes to build up and earn a following among authors, yet the high acceptance rates (and thus less discriminating journals) by no means constitute a majority in any of these categories among this sample, while all categories are represented among the journals boasting low acceptance rates.

Table 17 about here 


\section{Discussion}

This survey sampled a set of journals that share no more than an open source software platform, Open Journal Systems, which they use to manage and publish their content. Although this provided a relatively narrow focus among journals, the study did have close to 1,000 respondents, placing it among the larger studies of journal editors conducted on any basis. In some senses, this international set of journal drawn from across the disciplines are representative of the long-standing tradition in scholarly publishing. They conduct peer review of their submissions by drawing on an international pool of reviewers, leading to acceptance rates that are, in many although not all cases, comparable to those found among journals. The journals in this study rely on the interest, energy, and commitment of faculty members and graduate students, much as journals everywhere do, just as these journals rely, as most do, on software systems to reduce clerical and managerial expenses, while facilitating a distribution of workloads among editors. ${ }^{14}$

The journals in this sample are directed by multiple editors, and provide the typical range of editorial services for their submissions, if not as often hiring employees to undertake editorial tasks as traditional journals do. These journals owe a debt, if perhaps more so than other journals, to the indirect support of Google Scholar for indexing the contents of these journals on publication, making them open to discovery on the same grounds as other journals, while providing readers with a degree of quality control, through Google's page ranking and the citation counts that it provides in its search results.

Yet this sample also stands apart from the majority of journals. Where a small number of large commercial publishers now dominate journal publishing (Crow, 2005), this study found that commercial entities formed the smallest category of publisher. The scholar-publisher - or more accurately the group-of-scholars-as-publisher - is responsible for the majority of journals in this study, constituting a type that dates back to the earliest days of the journal, when Henry Oldenburg launched the Philosophical Transactions as an independent, albeit commercial, venture. The scholarpublisher is now experiencing, this study suggests, a certain renaissance, facilitated by online, open access. ${ }^{15}$

The journals represented in this study also mark an expansion in the global circulation of

\footnotetext{
14 The journals might be said to be running on what King, Macdonald, and Roderer refer to as "donated services" (1981, p. 118). Yet the universities underwrite this donation, by recognizing (if never enough) the service of editors, reviewers, and authors to journals as part of a faculty member's job, which it does for all journals, and it also underwrites the additional expenses (including surpluses and profits) of other journals, as it pays subscription fees.

15 This sudden increase in new titles is not without something of a parallel, as Ware and Mabe note that the "growth [in titles] did slightly accelerate in the post-war period 1944-78" largely as a result of commercial journal publishers responding to increased research funding $(2009$, p. 18).
} 
knowledge. Close to half of the journals in the sample are published in developing countries, contributing, as well, to the growth of a research and review culture (with all the ramifications for participation in a knowledge-based economy). ${ }^{16}$ As part of this growth, the journals that participated in this survey are decidedly younger, with fewer articles publishers, than the larger body of established commercial and society titles, subject to previous surveys. The journals in this sample are further distinguished by two closely related factors. First, open access is vital to their participation in this global circulation of knowledge (given what previous studies have established about traditional start-up costs and the extremely constrained ability of research libraries to take on new titles). Second, open access is made possible for this set of journals by the internet and open source software that have reduced publishing and distribution costs.

These journals are also in a position to contribute to future discussions about scholarly communication in light of their budgets, which appear to challenge what is often held up as the necessary and real cost of scholarly publishing, whether to prove the impossibility of open access publishing or to set a publication charge fee for authors to pay for open access. ${ }^{17}$ The challenge posed by this set of journals becomes starkly apparent, whether the one compares the first copy costs from this journal sample of $\$ 188.39$ per article, at roughly a tenth of the industry standard over the last decade (RIN 2008, p. 35), or the annual budget for the majority of these journals, which stands at less than what are held to be the "fixed" costs $(\$ 3,800)$ of a single article (Ware \& Mabe, 2009, p. 52). These figures bear comparison with work that Ted Bergstrom did to establish how the quality and quantity of journal content are no longer related to subscription price, when he demonstrated that the best journals in economics, which are published by scholarly societies, cost subscribers five-times less per-page than the lower ranked commercially published journals (2001, p. 3). While the corporate sector takes an increasing share of the journal market, the independent scholar-publisher is proving to be the source of more new titles. This study only adds to the evidence attesting to how out of balance and economically irrational the current system of scholarly publishing is, and, by the same token, how important it might be for the academic community, perhaps led by the research libraries and scholarly societies, to seek a more rational and fair way to both raise the overall quality of scholarly communication, which a more equitable distribution of funding would undoubtedly do,

\footnotetext{
${ }^{16}$ The strong global level of growth among the journals in this sample needs to be compared to the long-term growth rate of journals otherwise, which has matched the increase of "US R\&D workers," as Ware and Mabe note (2009, p. 23).

${ }^{17}$ Colin G. Scanes Poultry Science Editor-in-Chief has posted an open letter dated January 20, 2010 to the scholarly world on this theme: "Who is to pay the very real costs of producing journals with this move to open access?" "How many journals will disappear if we go to a completely open access approach?" and "As a journal editor with, at present, a positive cash flow, we can and do waive page charges from papers from institutions in developing countries that cannot afford to pay these. We will not be able to continue this if there is a major reduction in revenue"; Poultry Science Association, Champaign, IL, http://www.dcprinciples.org/ostp/PSA.pdf.
} 
while fostering the openness of this marketplace of (peer-reviewed) ideas.

Now concerns have been expressed by researchers about journal proliferation more generally (RIN, 2009), and it is true that only a very small number of journals from this community have yet to acquire the high-quality markers of scholarly publishing. ${ }^{18}$ On the other hand, and in favor of scholarly largesse, this same Research Information Network study (2009) found that researchers are citing more journal articles than they have in the past, while a long-term series of studies of scientist reading habits shows that they are continuing to increase the number of articles they read from a wider range of journals by drawing on electronic sources (Tenopir, King, Edwards, $\& \mathrm{Lu}, 2009)$.

\section{Conclusion}

Open Journal Systems represents an experiment, now into its eighth year, on the effect that open source tools can have on journal publishing. This study documents how such tools have facilitated a revitalization of scholar-published peer-reviewed journals that are produced on a global scale and are universally available. It establishes the degree to which journals deploying OJS may be regarded as part of a larger series of digital-era experiments in scholarly communication, involving not just open access but open data, open archives, open source software, and open research instrumentation initiatives (Atkins et al., 2003). The academic community's commitment to this opening of research and scholarship, is reflected in the extra work it takes to ensure this level of openness, which often involving new systems for managing scholarly community. It reflects among a growing portion of that community a sense of responsibility for, and the value in, sharing what is learned. The priority given to this sharing reflects an intellectual property of this learning may well be thought to distinguish it, we are tempted to conclude, from other forms of intellectual property.

This study also adds to the case for rethinking the financing of scholarly communication. The current model of scholarly publishing, with the two principal areas of growth operating at the economic extremes of major corporate publisher and independent collections of scholars, seems highly inefficient, in light of the contribution that both sectors are making to the circulation of knowledge. The scholar-publisher is mounting an effective response to the current hold that large commercial and society publishers have on research library budgets by pursuing a model of cooperative participation in the global circulation of peer-reviewed literature. It then falls to the rest

\footnotetext{
18 Among quality markers achieved by journals using OJS, see, for example, Journal of Legal Analysis (Harvard University Press); International Journal of the Commons (with guest-editor, author, and editorial board member 2009 Nobel Laureate in Economics Elinor Ostrom); Journal of Medical Internet Research (ISI Web of Science's second highest Impact Factor in health sciences); and Knowledge Management for Development Journal (taken over by a major corporate publisher, Taylor and Francis).
} 
of the academic community, perhaps led by the research libraries, to see that the journals represented by this study need to figure in future considerations of this multi-billion-dollar investment in scholarly communication (with $\$ 8$ billion devoted annually for science, technology and medicine journals alone; Ware \& Mabe, 2009). Such an investment may appear better directed toward underwriting, for the benefit of humankind, universal access to the scholarly literature. Were the academic community willing, there is enough money on the table, this study suggests, to make this a reality in the years ahead. 


\section{References}

Atkins, D., Droegemeier, K.K., Feldman, S. I., Garcia-Molina, H., Klein, M.L., Messerschmitt, D.G., Messina, P., Ostriker, J.P., \& Wright, M.H. (2003). Revolutionizing science and engineering through cyberinfrastructure: Report of the National Science Foundation Blue-Ribbon Advisory Panel on Cyberinfrastructure. Washington DC: National Science Foundation.

Bergstrom, T. C. (2001). Free labor for costly journals? Journal of Economic Perspectives. 15, 183-98. http://www.econ.ucsb.edu/ tedb/Journals/jeprevised.pdf, accessed November 25, 2008.

Björk, B-C., Roos, A., \& Lauri, M. (2009). "Scientific journal publishing: yearly volume and open access availability" Information Research, 14(1) paper 391. Available from 12 January, 2009 at http://InformationR.net/ir/14-1/paper391.html.

Cambridge Economic Policy Associates. (CEPA). (2008). Activities, costs and funding flows in the scholarly communications system in the UK, A report commissioned by the Research Information Network, London.

Crow, R. (2005). Description of mixed market for peer reviewed scholarly journals. Unpublished paper, SPARC, Washington, DC.

Cyzyk, M. \& Choudhury, S. (2008). A survey and evaluation of open-source electronic publishing systems. Unpublished paper, Sheridan Libraries, Johns Hopkins University, Baltimore, MD. https://wiki.library.jhu.edu/display/epubs/.

Davis, P. M., Lewenstein, B. V., Simon, D. H., Booth, J. G., \& Connolly, M. J. L. (2008). Open access publishing, article downloads, and citations: randomised controlled trial BMJ, 337(a568). http://www.bmj.com/cgi/doi/10.1136/bmj.a568.

Elsevier. (2009). Elsevier at a glance. Kidlington UK: Elsevier. http://www.elsevier.com/wps/find/intro.cws_home/ataglance.

Eysenbach, G. (2006). Citation advantage of open access articles. PLoS Biology, 4(5). http://dx.doi.org/10.1371/journal.pbio.0040157.

Fry, B. M., \& White, H. S. (1976). Publishers and libraries: A study of scholarly and research journals. Lexington, Massachusetts: Lexington Books.

Garvey, W. D. (1979). Communication: The essence of science. London: Pergamon.

Harnad, S., Brody, T., Vallieres, F., Carr, L., Hitchcock, S., Gingras, Y., Oppenheim, C., Hajjem, C., \& Hilf, E. (2008). The access/impact problem and the Green and Gold roads to open access: An update. Serials review, 34(1), 36-40. http://eprints.ecs.soton.ac.uk/15852/.

Hitchcock, S. (2009). The effect of open access and downloads ('hits') on citation impact: A bibliography of studies. Unpublished paper, Open Citation Project.

http://opcit.eprints.org/oacitationbiblio.html, accessed November 25, 2008.

Houghton, J. W., Rasmussen, B., Sheehan, P. J., Oppenheim, C., Morris, A., Creaser, C., Greenwood, H., Summers, M., \& Gourlay, A. (2009) Economic implications of alternative scholarly publishing

models: exploring the costs and benefits. Retrieved from The Joint Information Systems Committee (JISC) website: http://www.jisc.ac.uk/media/documents/publications/

rpteconomicoapublishing.pdf

King, D. W. (2007). The cost of journal publishing: a literature review and commentary. Learned Publishing, 20, 85-106. doi: 10.1087/174148507X183551

King, D. W., Macdonald D. D., \& Roderer, N K. (1981). Scientific journals in the United States: Their production, use and economics. Stroudsburg, PA: Hutchinson Ross.

King D. W. \& Tenopir, C. (1998). Economic Cost Models of Scientific Scholarly Journal. Paper presented to the ICSU Press Workshop, Keble College, Oxford, UK, 31 March to 2 April. http://www.bodley.ox.ac.uk/icsu/kingppr.htm

Kronick, D. A. (2004). "Devant le deluge" and other essays on early modern scientific communication. Lanham, MD: Scarecrow.

Kronick, D. A. (1961). History of scientific publications. New York: Scarecrow.

Lorimer, R., Lynch, L., \& Provençal, J, (2006). Augmenting print: Planning for online journal publishing by social sciences and humanities journals in Canada. Canadian Association of Learned Journals, 
Burnaby, BC: Simon Fraser University. http://www.sshrc.ca/site/about-

crsh/publications/cajl_report_e.pdf

Machlup, F., \& Leeson, K. \& Associates (1978). Information through the printed word: The dissemination of scholarly, scientific, and intellectual knowledge. Vol. 2: Journals. New York, NY: Praeger.

McGuigan, G. S., \& Russell, R. D. (2008). The business of academic publishing: A strategic analysis of the academic journal publishing industry and its impact on the future of scholarly publishing. Electronic Journal of Academic and Special Librarianship, 9(3).

http://southernlibrarianship.icaap.org/content/v09n03/mcguigan_g01.html

Page, G., Campbell, R., \& Meadows, J. (1997). Journal publishing. Cambridge, Cambridge University Press

Prabha, C. (2007). Shifting from print to electronic journals in ARL university libraries. Serials Review, 33(1), 4-13.

Office of Science Information Service (OSIS). (1964). Characteristics of scientific journals 1949-1959, (NSF Publication No. 64-20). National Science Foundation. Washington, DC: Government Printing Office.

Research Information Network (RIN 2009). Communicating knowledge: How and why UK researchers publish and disseminate their findings. London: The Research Information Network. http://www.rin.ac.uk/our-work/communicating-and-disseminatingresearch/communicating-knowledge-how-and-why-researchers-pu.

Research Information Network (RIN 2008). Activities, costs and funding flows in the scholarly communications system. London: The Research Information Network. http://www.rin.ac.uk/ourwork/communicating-and-disseminating-research/activities-costs-and-funding-flowsscholarly-commu.

SQW. (2004). Costs and business models in scientific research publishing: A report commissioned by the Wellcome Trust. London, Wellcome Trust. Available at http://www.wellcome.ac.uk/en/1/awtpubrepcos.html.

Tenopir, C., \& King, D. W. (2000). Towards electronic journals: Realities for scientists, librarians and publishers, Washington DC: Special Libraries Association.

Tenopir, C., \& King, D. W. (1998). Designing the future of electronic journals with lessons learned from the past: economic and use patterns of scientific journals. IEEE Proceedings, http://www.umanitoba.ca/libraries/engineering/mla/e-journals.pdf

Tenopir, C., King, D. W., Edwards, S., \& Wu, L. (2009). Electronic journals and changes in scholarly article seeking and reading patterns. Aslib Proceedings: New Information Perspectives, 61(1), 5-32.

Tumbleson, R., \& Brownson, H. L. (1954). Survey of Operations and Finances of Scientific Journals, Science, 119 (March 19), 357-359.

Vance, A. (2009, November 20). Open source as a model for business is elusive. New York Times, B1, B5.

Ware, M., \& Mabe, M. (2009). The STM Report: An overview of scientific and scholarly journals publishing. Retrieved from International Association of Scientific, Technical and Medical Publishers. http://www.stm-assoc.org/2009_10_13_MWC_STM_Report.pdf

Willinsky, J. (2009). The stratified economics of open access. Economic Analysis and Policy, 39(1), 53-70. http:/ / www.eap-journal.com/download.php?file $=691$

Willinsky, J. (2006). The access principle: The case for open access to research and scholarship. Cambridge, MA: MIT Press.

Willinsky, J. (2005). Open Journal Systems: An example of Open Source Software for journal management and publishing. Library Hi Tech, 23(4).

Willinsky, J., \& Mendis, R. (2007). Open Access on a zero budget: A case study of Postcolonial Text. Information Research, 12(3), http://informationr.net/ir/12-3/paper308.html

Willinsky, J., Murray, S., Kendall, C., \& Palepu, A. (2007). Doing medical journals differently: Open Medicine, Open Access, and academic freedom. Canadian Journal of Communication, 32(3), 595612. 


\section{Population of Journals by Continent}

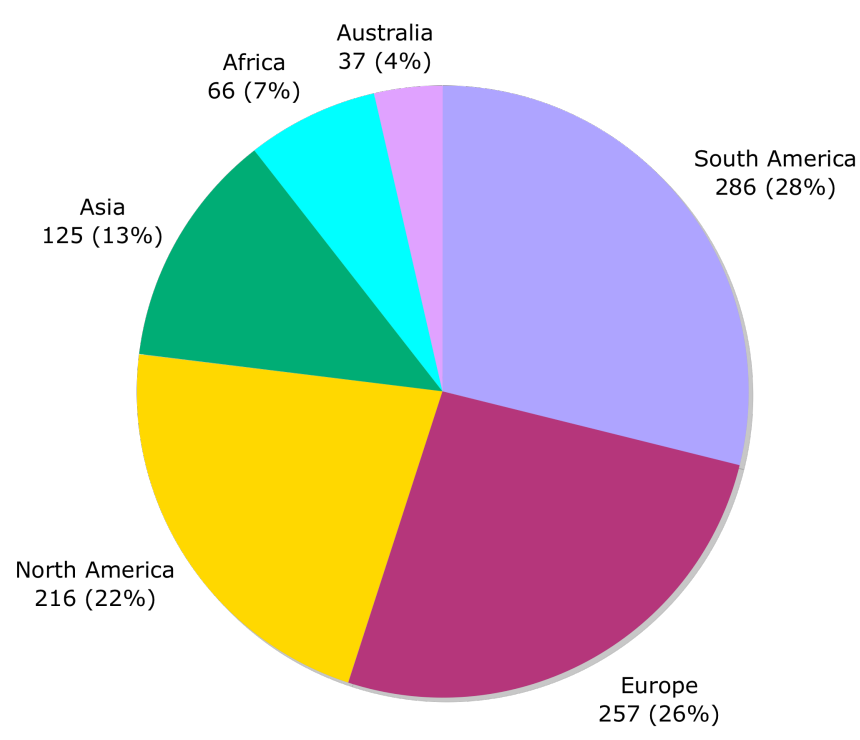

Figure 1. Distribution of journals using OJS by continent ( $N=987)$. 
Table 1

Topic Areas Covered by Journal by Number of Journals $(\mathrm{N}=980)$

\begin{tabular}{lc}
\hline Journal Topic Areas & Journals (\%) \\
\hline Sciences & $392(40)$ \\
Social sciences & $298(30)$ \\
General works (multidisciplinary) & $182(19)$ \\
Humanities & $108(11)$ \\
\hline
\end{tabular}


Table 2

Organizations that Sponsor or Publish Journal by Number of Journals (N=958)

\begin{tabular}{lc}
\hline \multicolumn{1}{c}{ Journal Sponsor } & Journals (\%) \\
\hline Academic department & $491(51)$ \\
Scholarly association or society & $307(32)$ \\
Non-profit publisher & $153(16)$ \\
Research unit & $145(15)$ \\
Independent group & $93(10)$ \\
Commercial publisher & $58(6)$ \\
Other & $150(16)$ \\
\hline
\end{tabular}

Note. Respondents were able to select more than one sponsor or publisher. 
Table 3

Date of Oldest Issue Available Online by Number of Journals

\begin{tabular}{cccccccccc}
\hline & $n$ & $\begin{array}{c}1872- \\
1900\end{array}$ & $\begin{array}{c}1901- \\
1950\end{array}$ & $\begin{array}{c}1951- \\
1960\end{array}$ & $\begin{array}{c}1961- \\
1970\end{array}$ & $\begin{array}{c}1971- \\
1980\end{array}$ & $\begin{array}{c}1981- \\
1990\end{array}$ & $\begin{array}{c}1991- \\
2000\end{array}$ & $\begin{array}{c}2001- \\
2009\end{array}$ \\
\hline Oldest issue online & 859 & 1 & 9 & 4 & 9 & 19 & 21 & 92 & 704 \\
\hline
\end{tabular}




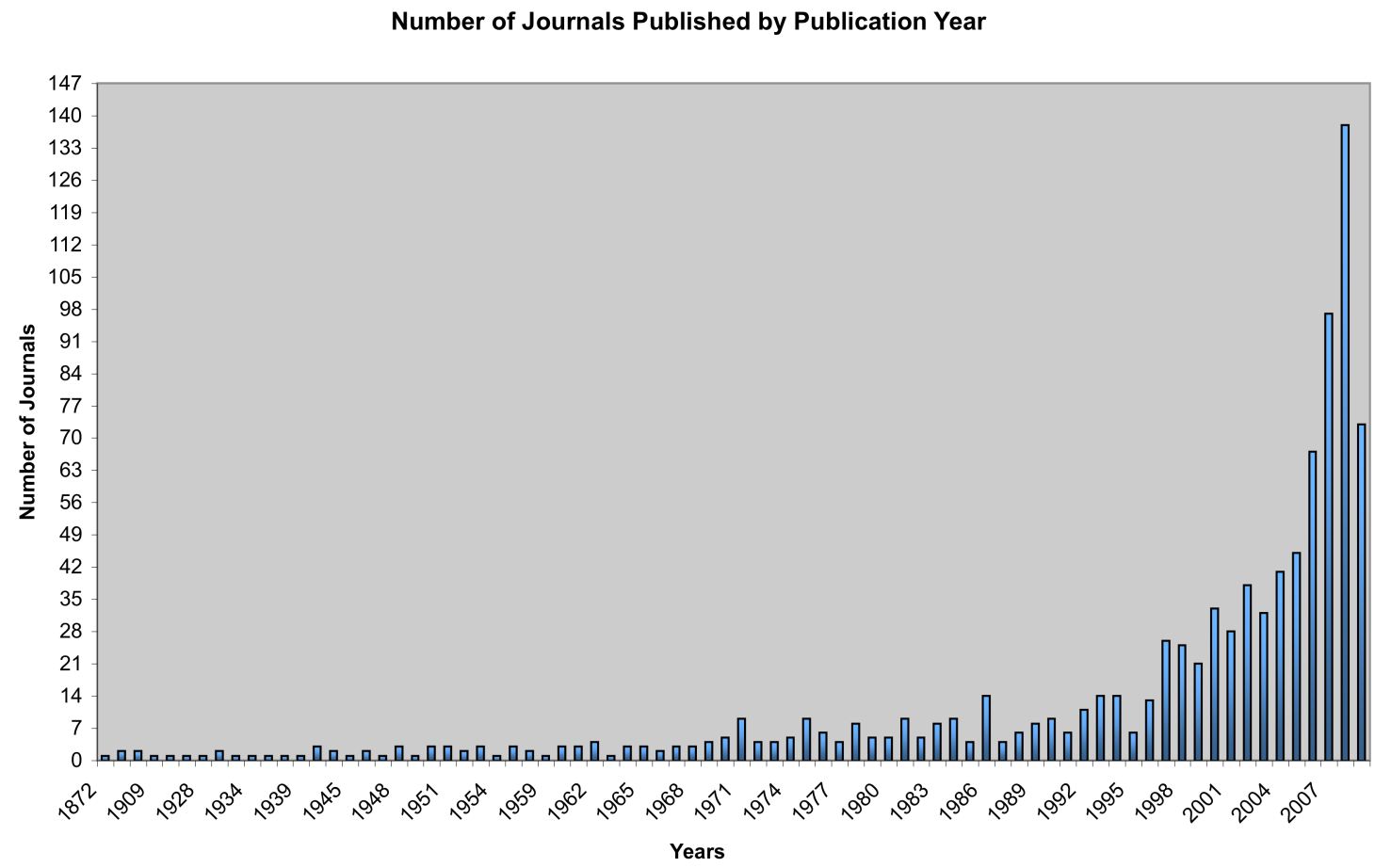

Figure 2. Year that journals using OJS started publishing.

Note. The survey was conducted in April of 2009 and thus that bar represents a third of a year. 
Table 4

Number of Submissions Received in Previous Month and Number of Articles Published in Previous Year by Number of Journals

\begin{tabular}{|c|c|c|c|c|c|c|c|c|c|c|c|}
\hline $\begin{array}{l}\text { Submissions/ } \\
\text { month }\end{array}$ & $n$ & $0^{a}$ & $1-10$ & $11-20$ & $21-30$ & $31-40$ & $41-50$ & $51-60$ & $>60$ & & \\
\hline $\begin{array}{c}\text { Journals } \\
(\%)\end{array}$ & $\begin{array}{c}919 \\
(100)\end{array}$ & $\begin{array}{l}76 \\
(8)\end{array}$ & $\begin{array}{l}530 \\
(58)\end{array}$ & $\begin{array}{l}184 \\
(20)\end{array}$ & $\begin{array}{l}58 \\
(6)\end{array}$ & $\begin{array}{l}30 \\
(3)\end{array}$ & $\begin{array}{c}8 \\
(1)\end{array}$ & $\begin{array}{c}8 \\
(1)\end{array}$ & $\begin{array}{l}25 \\
(3)\end{array}$ & & \\
\hline $\begin{array}{l}\text { Articles/ } \\
\text { Year }\end{array}$ & $n$ & $0^{\mathrm{a}}$ & $1-10$ & $11-20$ & $21-30$ & $31-40$ & $41-50$ & $51-60$ & $>60$ & $\begin{array}{c}\text { Articles } \\
\text { Mean }\end{array}$ & $S E$ \\
\hline $\begin{array}{c}\text { Journals } \\
(\%)\end{array}$ & $\begin{array}{c}746 \\
(100)\end{array}$ & $\begin{array}{l}60 \\
(8)\end{array}$ & $\begin{array}{l}173 \\
(23)\end{array}$ & $\begin{array}{l}214 \\
(29)\end{array}$ & $\begin{array}{l}104 \\
(4)\end{array}$ & $\begin{array}{l}63 \\
(8)\end{array}$ & $\begin{array}{l}36 \\
(5)\end{array}$ & $\begin{array}{l}28 \\
(4)\end{array}$ & $\begin{array}{l}68 \\
(9)\end{array}$ & 31 & 1.8 \\
\hline
\end{tabular}

Note. Mean for articles per year includes journals that reported one or more articles published. Mean could not be calculated fro submissions, as respondents selected span of numbers rather than providing a discrete number.

a The journal has not yet begun to accept submissions. 
Table 5

The Article Review Process by Number of Journals (N=919)

\begin{tabular}{lc}
\hline \multicolumn{1}{c}{ Editorial task } & Journals (\%) \\
\hline Articles are reviewed by journal editors & $649(71)$ \\
Articles are reviewed by outside (or external) peer reviewers & $818(89)$ \\
Peer reviewers are drawn from an international pool & $526(57)$ \\
More than one reviewer is assigned to a paper & $753(82)$ \\
Reviewers do not see authors' names & $644(70)$ \\
Peer reviewers' names are not shared with authors & $750(82)$ \\
\hline
\end{tabular}

Note. Respondents could select more than one task. 
Table 6

Percentage of Articles Accepted for Publication by Number of Journals (N=845)

\begin{tabular}{lllllllll}
\hline Acceptance rate & $<20 \%$ & $21-30 \%$ & $31-40 \%$ & $41-50 \%$ & $51-60 \%$ & $61-70 \%$ & $71-80 \%$ & $>80 \%$ \\
\hline Journals (\%) & $65(8)$ & $90(11)$ & $110(13)$ & $113(13)$ & $97(12)$ & $137(16)$ & $118(14)$ & $115(14)$ \\
\hline
\end{tabular}


Table 7

Characteristics of Editors Working on the Journals by Number of Journals

\begin{tabular}{|c|c|c|c|c|c|c|c|c|c|c|c|}
\hline No. Editors/journal & $\mathrm{n}$ & 0 & $1-5$ & $6-10$ & $11-15$ & $16-20$ & $21-25$ & $26-50$ & $>50$ & Mean & $S E$ \\
\hline $\begin{array}{c}\text { Editing journal } \\
(\%)\end{array}$ & $\begin{array}{l}883 \\
(100)\end{array}$ & $\mathrm{N} / \mathrm{A}$ & $\begin{array}{l}621 \\
(70)\end{array}$ & $\begin{array}{l}123 \\
(14)\end{array}$ & $\begin{array}{l}55 \\
(6)\end{array}$ & $\begin{array}{l}29 \\
(3)\end{array}$ & $\begin{array}{l}16 \\
(2)\end{array}$ & $\begin{array}{l}30 \\
(3)\end{array}$ & $\begin{array}{c}9 \\
(1)\end{array}$ & 7 & 0.4 \\
\hline $\begin{array}{c}\text { 1st time editors } \\
(\%)\end{array}$ & $\begin{array}{c}746 \\
(100)\end{array}$ & $\begin{array}{l}138 \\
(19)\end{array}$ & $\begin{array}{l}527 \\
(70)\end{array}$ & $\begin{array}{l}56 \\
(8)\end{array}$ & $\begin{array}{l}14 \\
(2)\end{array}$ & $\begin{array}{c}6 \\
(1)\end{array}$ & $\begin{array}{c}0 \\
(0)\end{array}$ & $\begin{array}{c}2 \\
(0)\end{array}$ & $\begin{array}{c}3 \\
(0)\end{array}$ & 3 & 0.33 \\
\hline $\begin{array}{c}\text { International }^{\mathrm{a}} \\
(\%)\end{array}$ & $\begin{array}{c}761 \\
(100)\end{array}$ & $\begin{array}{l}458 \\
(60)\end{array}$ & $\begin{array}{l}213 \\
(28)\end{array}$ & $\begin{array}{l}50 \\
(6)\end{array}$ & $\begin{array}{l}18 \\
(2)\end{array}$ & $\begin{array}{l}10 \\
(1)\end{array}$ & $\begin{array}{c}4 \\
(1)\end{array}$ & $\begin{array}{c}6 \\
(1)\end{array}$ & $\begin{array}{c}2 \\
(0)\end{array}$ & 6 & 0.22 \\
\hline Hours/week & $\mathrm{n}$ & 0 & $1-5$ & $6-10$ & $11-15$ & $16-20$ & $21-25$ & $26-50$ & $>50$ & Mean & $S E$ \\
\hline $\begin{array}{c}\text { No. of editors } \\
(\%)\end{array}$ & $\begin{array}{c}785 \\
(100)\end{array}$ & N/A & $\begin{array}{l}410 \\
(52)\end{array}$ & $\begin{array}{l}216 \\
(28)\end{array}$ & $\begin{array}{l}56 \\
(7)\end{array}$ & $\begin{array}{l}59 \\
(8)\end{array}$ & $\begin{array}{l}11 \\
(1)\end{array}$ & $\begin{array}{l}32 \\
(4)\end{array}$ & $\begin{array}{l}1 \\
(0)\end{array}$ & 8 & 0.3 \\
\hline
\end{tabular}

anternational refers to editors living in countries other than the one that the journal is published in. 
Table 8

Who Does What in the Publication Process, by Number of Journals $(\mathrm{N}=919)$

\begin{tabular}{lccc}
\hline \multicolumn{1}{c}{ Staff Position } & Copyediting (\%) & Layout (\%) & Proofreading (\%) \\
\hline Journal editor & $695(76)$ & $532(58)$ & $646(70)$ \\
Employee & $226(25)$ & $327(36)$ & $239(26)$ \\
Article author & $274(30)$ & $139(15)$ & $454(49)$ \\
Student volunteer & $79(9)$ & $80(9)$ & $82(9)$ \\
Student employee & $73(8)$ & $91(10)$ & $70(7)$ \\
Other volunteer & $80(9)$ & $77(8)$ & $94(10)$ \\
\hline
\end{tabular}


Table 9

Basis of Staff Participation in Journal Role by Number of Journals

\begin{tabular}{lcccc}
\hline \multicolumn{1}{c}{ Role } & $n$ & No fee paid (\%) & Fee paid (\%) & N/A (\%) \\
\hline Editors & 829 & $637(77)$ & $136(16)$ & $56(7)$ \\
Journal managers & 784 & $496(63)$ & $196(25)$ & $92(12)$ \\
Peer reviewers & 807 & $723(90)$ & $53(7)$ & $31(4)$ \\
Graphic designers & 751 & $262(35)$ & $309(42)$ & $180(24)$ \\
Technical support & 765 & $339(44)$ & $281(37)$ & $145(19)$ \\
Clerical support & 713 & $257(36)$ & $178(25)$ & $278(39)$ \\
Promotional work & 708 & $312(44)$ & $93(13)$ & $303(43)$ \\
\hline
\end{tabular}

Note. Number in subsample (n) refers to those who responded to individual items. 
Table 10

Sources and Amounts of Annual Journal Revenue (USD) by Number of Journals

\begin{tabular}{|c|c|c|c|c|c|c|c|c|c|c|c|}
\hline Revenue & $n$ & $\$ 0$ & $\begin{array}{l}\$ 1- \\
100\end{array}$ & $\begin{array}{c}\$ 101- \\
500\end{array}$ & $\begin{array}{l}\$ 501- \\
1,000\end{array}$ & $\begin{array}{c}\$ 1,001- \\
5,000\end{array}$ & $\begin{array}{c}\$ 5,001- \\
10,000\end{array}$ & $\begin{array}{c}\$ 10,001- \\
100,000\end{array}$ & $>\$ 100 \mathrm{~K}$ & Mean & SE \\
\hline Subscriptions ${ }^{a}$ & 723 & 586 & 47 & 31 & 15 & 22 & 12 & 9 & 1 & $\$ 7,815$ & $\$ 4,915$ \\
\hline Advertising & 697 & 648 & 13 & 11 & 3 & 14 & 2 & 5 & 1 & $\$ 16,807$ & $\$ 11,734$ \\
\hline Member dues & 697 & 617 & 26 & 9 & 8 & 19 & 10 & 7 & 1 & $\$ 5,322$ & $\$ 1,977$ \\
\hline Publication fees & 704 & 640 & 19 & 17 & 5 & 13 & 5 & 5 & 0 & $\$ 3,188$ & $\$ 852$ \\
\hline Submission fees & 704 & 683 & 11 & 6 & 1 & 2 & 1 & 0 & 0 & $\$ 867$ & $\$ 384$ \\
\hline Pay-Per-View & 697 & 688 & 3 & 3 & 2 & 0 & 0 & 1 & 0 & $\$ 2,077$ & $\$ 1,745$ \\
\hline Reprint fees & 691 & 649 & 20 & 4 & 6 & 8 & 1 & 3 & 0 & $\$ 2,200$ & $\$ 805$ \\
\hline Endowment & 679 & 672 & 2 & 2 & 2 & 1 & 0 & 0 & 0 & $\$ 2,303$ & $\$ 1,219$ \\
\hline Grants & 682 & 599 & 0 & 5 & 3 & 33 & 15 & 26 & 1 & $\$ 15,594$ & $\$ 2,754$ \\
\hline Fundraising & 671 & 609 & 3 & 10 & 9 & 24 & 11 & 5 & 0 & $\$ 6,199$ & $\$ 1,735$ \\
\hline Subsidies & 673 & 450 & 11 & 18 & 23 & 73 & 32 & 64 & 2 & $\$ 15,024$ & $\$ 5,433$ \\
\hline Other sources & 534 & 488 & 8 & 3 & 8 & 11 & 8 & 7 & 0 & $\$ 26,475$ & $\$ 21,674$ \\
\hline
\end{tabular}

Note. The number in subsample (n) refers to those who responded to individual item. Means include only those journals that reported a revenue greater than zero for the item.

${ }^{a}$ Includes institutional and individual subscriptions. 
Table 11

Change in Subscriptions in Past Year

\begin{tabular}{lcccccc}
\hline \multicolumn{1}{c}{ Journals } & $n$ & $\begin{array}{c}\text { Journals with } \\
\text { increase in } \\
\text { subscribers }\end{array}$ & $\begin{array}{c}\text { Average } \\
\text { increase in } \\
\text { subscribers }\end{array}$ & $\begin{array}{c}\text { Journals with no } \\
\text { change in } \\
\text { subscribers }\end{array}$ & $\begin{array}{c}\text { Journals with } \\
\text { decrease in } \\
\text { subscribers }\end{array}$ & $\begin{array}{c}\text { Average } \\
\text { decrease in } \\
\text { subscribers }\end{array}$ \\
\hline $\begin{array}{l}\text { All journals with } \\
\text { subscriptions }\end{array}$ & 247 & $145(59 \%)$ & 124 & $62(25 \%)$ & $40(16 \%)$ & -177 \\
$\begin{array}{l}\text { Print and online by } \\
\text { subscription }\end{array}$ & 50 & $23(46 \%)$ & 108 & $19(38 \%)$ & $8(16 \%)$ & -480 \\
$\begin{array}{l}\text { Print by subscription; } \\
\text { online open access }\end{array}$ & 95 & $39(41 \%)$ & 143 & $41(43 \%)$ & $14(15 \%)$ & -111 \\
\hline
\end{tabular}

Note. As this table draws on data from two survey items with different response rates, the response rates of the two subcategories (rows 2 and 3) do not add up to "all journals with subscriptions." 
Table 12

Journal Access Policies by Number of Journals (N=829)

\begin{tabular}{lc}
\hline \multicolumn{1}{c}{ Policy } & Journals (\%) \\
\hline Open access to journal content & $688(83)$ \\
$\begin{array}{l}\text { Open access online/subscription for } \\
\text { print }\end{array}$ & $168(20)$ \\
Embargoed access & $70(8)$ \\
Partial open access & $15(2)$ \\
Permit immediate author self-archiving & $109(13)$ \\
Permit delayed author self-archiving & $11(1)$ \\
Subscription for print and online access & $87(11)$ \\
\hline
\end{tabular}

Note. Respondents could choose more than one policy. 
Table 13

Registered Readers and Subscribers by Number of Journals

\begin{tabular}{cccccccccc}
\hline $\begin{array}{c}\text { Registered } \\
\text { Readers }\end{array}$ & $n$ & 0 & $1-500$ & $\begin{array}{c}501- \\
1,000\end{array}$ & $\begin{array}{c}1,001- \\
5,000\end{array}$ & $\begin{array}{c}5,001- \\
10,000\end{array}$ & $\begin{array}{c}10,001- \\
100,000\end{array}$ & $\begin{array}{c}\text { Readers } \\
\text { Mean }\end{array}$ & $S E$ \\
\hline Journals (\%) & $563(100)$ & $48(9)$ & $387(69)$ & $63(11)$ & $53(9)$ & $2(0)$ & $10(2)$ & 1,155 & 281 \\
\hline & & & & & & & & & \\
\hline \multirow{2}{*}{ Subscribers } & $n$ & 0 & $1-500$ & $\begin{array}{c}501- \\
1,000\end{array}$ & $\begin{array}{c}1,001- \\
5,000\end{array}$ & $\begin{array}{c}5,001- \\
10,000\end{array}$ & $\begin{array}{c}10,001- \\
100,000\end{array}$ & $\begin{array}{c}\text { Subscribers } \\
\text { Mean }\end{array}$ & $S E$ \\
\hline Journals (\%) & $388(100)$ & $110(28)$ & $214(55)$ & $30(8)$ & $29(8)$ & $3(1)$ & $2(1)$ & 611 & 98 \\
\hline
\end{tabular}

Note. Means include only those journals that reported some readers or subscribers. 
Table 14

Annual Journal Expenses (USD) by Number of Journals

\begin{tabular}{lcccccccccccc}
\hline \multicolumn{1}{c}{ Expense } & $n$ & $\$ 0$ & $\$ 1-100$ & $\$ 101-$ & $\$ 500-$ & $\$ 1,001-$ & $\$ 5,000-$ & $\$ 10,001-$ & $>\$ 100 \mathrm{~K}$ & Mean & $S E$ \\
\hline Editorship & 657 & 522 & 14 & 23 & 11 & 54 & 14 & 20 & 1 & $\$ 6,442$ & $\$ 1,179$ \\
Management & 652 & 474 & 20 & 32 & 24 & 46 & 28 & 26 & 2 & $\$ 9,053$ & $\$ 2,054$ \\
Copyediting & 630 & 478 & 13 & 35 & 35 & 46 & 13 & 10 & 0 & $\$ 3,973$ & $\$ 851$ \\
Article layout & 630 & 454 & 16 & 52 & 32 & 61 & 9 & 6 & 0 & $\$ 2,756$ & $\$ 619$ \\
Proofreading & 622 & 504 & 15 & 36 & 30 & 30 & 5 & 2 & 0 & $\$ 1,613$ & $\$ 225$ \\
Website & 625 & 457 & 63 & 54 & 31 & 19 & 0 & 1 & 0 & $\$ 664$ & $\$ 98$ \\
Customization & 599 & 545 & 11 & 21 & 7 & 14 & 0 & 1 & 0 & $\$ 1,955$ & $\$ 925$ \\
Technical & 617 & 494 & 19 & 38 & 27 & 32 & 3 & 4 & 0 & $\$ 2,127$ & $\$ 450$ \\
Promotion & 606 & 536 & 17 & 24 & 12 & 13 & 2 & 2 & 0 & $\$ 1,991$ & $\$ 753$ \\
Subscription costs & 599 & 577 & 0 & 6 & 2 & 10 & 0 & 3 & 1 & $\$ 12,728$ & $\$ 9,002$ \\
Journal printing & 635 & 379 & 4 & 29 & 26 & 111 & 39 & 44 & 3 & $\$ 9,463$ & $\$ 2,055$ \\
Postage & 627 & 396 & 51 & 65 & 49 & 49 & 9 & 8 & 0 & $\$ 2,526$ & $\$ 541$ \\
Other & 544 & 408 & 22 & 39 & 37 & 29 & 6 & 2 & 1 & $\$ 5,447$ & $\$ 3,693$ \\
\hline
\end{tabular}

Note. Number in subsample $(n)$ refers to those who responded to individual item. Means include only those journals that reported a revenue greater than zero for the item. 
Table 15

Total Journal Revenues and Expenses by Number of Journals

\begin{tabular}{ccccccccc}
\hline Revenues & $\mathrm{N}$ & $\$ 0$ & $\$ 1-1,000$ & $\$ 1,001-10 \mathrm{~K}$ & $\$ 10,001-50 \mathrm{~K}$ & $>\$ 50 \mathrm{~K}$ & Mean & $S E$ \\
\hline Journals (\%) & $761(100)$ & $336(44)$ & $120(16)$ & $180(24)$ & $101(13)$ & $24(3)$ & $\$ 28,479$ & $\$ 9,711$ \\
\hline \multicolumn{1}{c}{ Expenses } & $\mathrm{N}$ & $\$ 0$ & $\$ 1-1,000$ & $\$ 1,001-10 \mathrm{~K}$ & $\$ 10,001-50 \mathrm{~K}$ & $>\$ 50 \mathrm{~K}$ & Mean & $S E$ \\
\hline Journals (\%) & $711(100)$ & $208(29)$ & $139(20)$ & $222(31)$ & $115(16)$ & $27(4)$ & $\$ 16,951$ & $\$ 5,542$ \\
\hline
\end{tabular}

Note. Means include only those journals that reported revenues/expenses greater than zero. 
Table 16

Annual Operating Balances by Number of Journals (N=773)

\begin{tabular}{cccccccccc}
\hline & \multicolumn{4}{c}{ Deficit } & \multicolumn{3}{c}{ Even } & \multicolumn{2}{c}{ Surplus } \\
\hline Annual & $>-\$ 10,000$ & $-\$ 10,000-$ & $-\$ 5,000-$ & $-\$ 1,000-$ & $-\$ 99-$ & $+\$ 100-$ & $+\$ 1,001-$ & $+\$ 5,001-$ & $>\$ 10,000$ \\
Balance & & 5,001 & 1,001 & 100 & +99 & 1,000 & 5,000 & 10,000 & $17(2)$ \\
\hline Journals $(\%)$ & $38(5)$ & $30(4)$ & $68(9)$ & $80(10)$ & $397(51)$ & $60(8)$ & $51(7)$ & $32(4)$ \\
\hline
\end{tabular}


Table 17

Distribution of Journals by High or Low Submission Acceptance Rates

\begin{tabular}{|c|c|c|c|}
\hline Submission Acceptance Rate & $n$ & $\begin{array}{l}\text { Low Acceptance } \\
(\geq 30 \%, n=155)\end{array}$ & $\begin{array}{l}\text { High Acceptance } \\
(\geq 70 \%, n=233)\end{array}$ \\
\hline Modest budget journals (> $\$ 10,000 / a)$ & 134 & $23(17 \%)$ & $28(21 \%)$ \\
\hline Minimal budget journals $(\leq \$ 1,000 / a)$ & 306 & $49(16 \%)$ & $106(35 \%)$ \\
\hline Older journals $(\leq 1990)$ & 194 & $32(16 \%)$ & $42(22 \%)$ \\
\hline Newer Journals (> 1990) & 612 & $112(18 \%)$ & $187(31 \%)$ \\
\hline Open access (entirely) journals & 619 & $101(16 \%)$ & $181(29 \%)$ \\
\hline Subscription revenue journals & 57 & $14(25 \%)$ & $15(26 \%)$ \\
\hline Society sponsored journal & 259 & $56(22 \%)$ & $65(25 \%)$ \\
\hline Independent group & 62 & $12(19 \%)$ & $22(35 \%)$ \\
\hline Developed continent & 415 & $92(22 \%)$ & $121(29 \%)$ \\
\hline Developing continent & 423 & $61(7 \%)$ & $110(26 \%)$ \\
\hline
\end{tabular}

Note. The number (n) of journals refers to total number of journals in the category defined by the first column for which submission rates are known. 